УДК 619:616-084:619.616.921.5:636.1

(C) 2012

Мартинова О. Л., аспірант *

Полтавська державна аграрна академія

\title{
ІМУНОПРОФІЛАКТИКА ГРИПУ КОНЕЙ
}

\section{Рецензент - доктор ветеринарних наук А. А. Замазій}

Детально розглянуто зареєстровані в Україні вакиини, шзо використовуються для імунопрофілактики грипу коней. Було проведено порівняння їх антигенної структури та складу. Досліджено схеми вакцинацій, запропоновані виробниками даних імунобіологічних препаратів (Форт додж Енімал

Хелз, США; АТ «Біовета», Чехія). Розглянуто можливі причини прориву імунітету за вакцинацій. Згідно з ичим даються рекомендації щзодо застосування окремих вакцин проти грипу коней у конегосподарствах України. Виявлено, щзо для активної імунізації коней доцільно використовувати вакиини з тим набором антигенів, щзо відповідає вірусному пейзажу конкретного господарства, а також залежить від того, чи є необхідність вакиинувати коней проти правця кожен рік.

Ключові слова: грип коней, імунітет, вакциина, схема вакцинації, імунопрофілактика.

Постановка проблеми. Робота іподромів та племінних конегосподарств може значною мірою ускладнюватися спалахами гострої контагіозної хвороби - грипу коней.

За виникнення цього захворювання господарство оголошується неблагополучним. У такому випадку вводяться обмеження, згідно 3 якими забороняється перегрупування поголів'я, введення і виведення коней за межі господарства.

Для того, щоб ефективно боротися 3 цим гострим висококонтагіозним захворюванням коней, необхідне ізольоване утримання та окреме обслуговування хворих і підозрілих на захворювання тварин. Хворі коні можуть раптово загинути від серцевої недостатності, що, в свою чергу, вимагає припинення тренінгу та їх випробувань. Останнє порушує плани роботи фахівців із підготовки тварин до виступу в призових скачках і заїздах.

Саме тому хворобу значно легше попередити, ніж потім ліквідувати їі наслідки. Вибір ефективної схеми вакцинації - запорука здорового конепоголів'я.

Аналіз основних досліджень і публікацій, у яких започатковано розв'язання проблеми.
Швидкому розповсюдженню вірусу сприяє наявність у табуні неімунних коней. Перехворілі коні набувають імунітету до повторного зараження гомологічним типом вірусу тривалістю не менше одного року. Мінливість вірусу та існування двох основних імунологічних підтипів A/equine 1 та A/equine 2 - не виключають можливості повторного захворювання перехворілих коней $[1,2]$.

Мета і методи досліджень. Метою роботи було вивчення зареєстрованих в Україні вакцин проти грипу коней i визначення, якою 3 них краще проводити активну імунізацію тварин. У процесі дослідження нами використовувалися теоретичні методи, а саме збір та опис фактів із літературних першоджерел, їх аналіз (співставлення, порівняння, класифікація).

Результати досліджень. На сьогоднішні в Україні зареєстровано та використовується три імунобіологічні засоби проти грипу коней [3-6]:

- вакцина рідка інактивована проти грипу коней та правця Дуваксін IE-T плюс (Duvaxin IE-T Plus) виробництва Форт додж Енімал Хелз (США);

- Флюеквін, Fluequin - вакцина інактивована проти грипу коней виробництва АТ «Біовета» (Чехія);

- Флюеквін T, Fluequin T - вакцина інактивована проти грипу та правцю коней виробництва АТ «Біовета» (Чехія).

Антигенна структура вакцин, що зареєстровані в Україні, подана в таблиці.

Із метою профілактики інфекції щепленню підлягають:

- тварини, які належать кінним заводам, спортивним товариствам, приватним підприємствам i циркам;

- спортивні й племінні коні, які направляються за межі господарств.

У разі загрози виникнення грипу все конепоголів'я (незалежно від форм власності) вакцинують зазначеними вакцинами.

* Науковий керівник-кандидат ветеринарних наук С. Б. Передера 
СТОРІНКА МОЛОДОГО ВЧЕНОГО

\begin{tabular}{|c|c|c|}
\hline \multicolumn{3}{|c|}{ Антигенна структура вакцин } \\
\hline Вакцина & Антигенний вміст & Кількість антигену \\
\hline \multirow{4}{*}{$\begin{array}{l}\text { Дуваксін } \\
\text { IE-T плюс }\end{array}$} & $\begin{array}{c}\text { Інактивований вірус грипу } \\
\text { A/equi-1/Prague/56 }\end{array}$ & $15 \mu \mathrm{g}$ \\
\hline & $\begin{array}{c}\text { Інактивований вірус грипу } \\
\text { A/equi-2/Miami/63 }\end{array}$ & $15 \mu \mathrm{g}$ \\
\hline & $\begin{array}{c}\text { Інактивований вірус грипу } \\
\text { A/equi-2/Suffolk/89 }\end{array}$ & $15 \mu \mathrm{g}$ \\
\hline & Purified tetanus toxid & $15 \mathrm{Lf}$ \\
\hline \multirow{3}{*}{ Флюеквін } & $\begin{array}{c}\text { Інактивований вірус грипу } \\
\text { A/Equi } 1 / \text { Прага } 56 \\
\end{array}$ & мінім. $160 \mathrm{HAU}$ \\
\hline & $\begin{array}{c}\text { Інактивований вірус грипу } \\
\text { A/Equi 2/Морава } 95 \text { (європейський тип) }\end{array}$ & мінім. $320 \mathrm{HAU}$ \\
\hline & $\begin{array}{c}\text { Інактивований вірус грипу } \\
\text { A/Equi 2/Брно } 97 \text { (американський тип) }\end{array}$ & мінім. $320 \mathrm{HAU}$ \\
\hline \multirow{4}{*}{ Флюеквін Т } & $\begin{array}{c}\text { Інактивований вірус грипу } \\
\text { A/Equi 1/Прага } 56\end{array}$ & мінім. $160 \mathrm{HAU}$ \\
\hline & $\begin{array}{c}\text { Інактивований вірус грипу } \\
\text { A/Equi 2/Морава } 95 \text { (європейський тип) }\end{array}$ & мінім. $320 \mathrm{HAU}$ \\
\hline & $\begin{array}{c}\text { Інактивований вірус грипу } \\
\text { A/Equi 2/Брно } 97 \text { (американський тип) }\end{array}$ & мінім. $320 \mathrm{HAU}$ \\
\hline & Anatoxinum tetanicum purificatum & мінім. $150 \mathrm{IU}$ \\
\hline
\end{tabular}

Обов'язковій вакцинації проти грипу підлягають усі коні - учасники змагань, на іподромах, аукціонах, при відправленні за кордон [6].

Схема вакцинації для вакцин «Флюеквін Т» i «Флюеквін», а також для вакцини «Дуваксін IET плюс» схожі: перша - головна вакцинація проводиться в 3-6-місячному віці (для вакцини «Дуваксін IE-T плюс» - у 5-6-місячному віці), а через 4-6 тижнів проводиться ревакцинація. Наступна ревакцинація проти грипу проводиться через кожні 6-12 місяців у залежності від інфекційної ситуації. Ревакцинація жеребих кобил проводиться в останньому триместрі жеребності, не пізніше ніж за місяць до планової вижеребки в дозі 1 мл глибоко внутрішньом'язово. Лошат, які народилися у кобил, вакцинованих перед вижеребкою, рекомендовано вакцинувати у 6-місячному віці у зв'язку 3 колостральним імунітетом.

Не рекомендується проводити щеплення хворим тваринам. Побічної дії у вакцин не виявлено.

Крім того необхідно пам'ятати і про те, що кількість щеплених коней в одному клубі або конегосподарстві має становити не менше $80 \%$. Якщо цей відсоток менший, то окремо взятий, щеплений за всіма правилами, кінь має ризик захворіти в разі занесення інфекції в господарство. Це відбувається внаслідок того, що хвора тварина виділяє в зовнішнє середовище величез- ну кількість збудника, а імунна система не встигає продукувати адекватну кількість антитіл. Така ситуація називається «прорив» імунітету.

Вибір вакцини, яку необхідно використовувати в даному конкретному конегосподарстві, залежить від вірусного пейзажу господарства і від того, чи $є$ необхідність вакцинувати коней проти правця кожен рік. Згідно з інструкцією, вакцинація коней проти правця проводиться раз у три роки. Тому, з нашого погляду, для щорічної вакцинації коней проти грипу краще надавати перевагу вакцинам, що містять інактивований вірус грипу тих штамів, що відповідають вірусному пейзажу господарства, а раз на три роки використовувати вакцину, яка крім цього містить ще й правцевий анатоксин.

\section{Висновки:}

В Україні нині зареєстровано й використовується три імунобіологічні засоби проти грипу коней:

- вакцина рідка інактивована проти грипу коней та правця Дуваксін IE-T плюс (Duvaxin IE-T Plus) виробництва Форт додж Енімал Хелз (США);

- Флюеквін, Fluequin - вакцина інактивована проти грипу коней виробництва АТ "Біовета" (Чехія);

- Флюеквін T, Fluequin T - вакцина інактивована проти грипу та правцю коней виробництва АТ "Біовета" (Чехія). 
Дві із запропонованих вакцин («Дуваксін IE-T плюс» і «Флюеквін Т») мають у своєму складі правцевий анатоксин.

Вакцини відрізняються між собою за антигенним складом штамів вірусу грипу.

\section{БІБЛІОГРАФІЯ}

1. Автореферат дисертації на здобуття звання кандидата ветеринарних наук: 16.00 .03 / В. В. Гусаков; Нац. аграр. ун-т. - К., 2000. - 17 с.

2. Гусаков (Локота) В. В. Епізоотична ситуація щодо грипу коней на Київському державному іподромі в 1995-1996 рр. // Ветеринарна медицина України. - 1998. - № 10. - С. 32-33.

3. Інструкція до застосування вакцини інактивованої проти грипу та правцю Флюеквін Т.

4. Інструкція до застосування вакцини інактивованої проти грипу та правцю Дуваксін IE-T
Для активної імунізації коней доцільно використовувати вакцини 3 тим набором антигенів, що відповідає вірусному пейзажу конкретного господарства.

плюс.

5. Інструкція до застосування вакцини інактивованої проти грипу Флюеквін.

6. Інструкція про заходи з профілактики та ліквідації захворювання коней грипом.

7. Старчеус А. П., Міроненко А. П., Гусаков В. В. Результати вивчення гуморального протигрипозного імунітету у коней // Зб. : Розвиток ветеринарної науки в Україні : здобутки та проблеми. Матеріали Міжнародної науково-практичної конференції. - Х., 1997. - С. 143-144. 